\title{
Yield Performance of Barley Hybrids (Hordeum vulgare L.) under Drought stress and non-stressed Conditions
}

\author{
Yadgar Ali Mahmood ${ }^{1}$, Halgurd Nasraden Hassan², Masood saber Mohammed ${ }^{3}$ \\ ${ }^{1}$ Department of Field Crops, College of Agricultural Engineering Sciences, University of Garmian, As Sulaymaniayah, Kurdistan Region, Iraq \\ ${ }^{2 \& 3}$ Department of Agricultural project management, Kalar Technical Institute, Sulaimani Polytechnic University, As Sulaymaniayah, Kurdistan \\ Region, Iraq
}

Received 06 March 2021; revised 14 March 2021;

accepted 26 March 2021; available online 08 April 2021

doi: $10.24271 /$ psr.20

\begin{abstract}
This study was carried out at the experiment field, Kalar Technical Institute, Garmian Region in two growing seasons of 2016-2017 and 2017-2018 in order to evaluate the growth and yield potentials of barley under water stressed using hybrids as a source of wide range of genotypic variations. Therefore, five $\mathrm{F}_{2}$ barley hybrids (Hordeum vulgare $\mathrm{L}$.) were screened for grain yield, biomass dry matter, plant height and harvest index under irrigated and drought conditions. Results showed that there was no effect of drought on grain yield $(\mathrm{P}>0.05)$ in 2017, while significantly reduced yield in 2018 and across-year mean $(\mathrm{P}<0.05)$. The grain yield reduction was between $8.8 \%$ for genotype (3//1) and 16.3\% for genotype (3//18) averaging over years. Biomass dry matter, plant height and harvest index were also affected by drought in 2018 and cross-year mean $(\mathrm{P}<0.05)$, but not in 2017 due to difference in drought stress times and periods. Genotypes were significantly differed for all traits except for plant heights. Averaging over years, grain yield was in the range 299.1 (3//1) to $336.2 \mathrm{~g} \mathrm{~m}^{-2}$ (3//14) under irrigated condition, and $267.8(3 / / 5)$ to $302.3 \mathrm{~g} \mathrm{~m}^{-2}$ (3//4) under unirrigated condition ( $\left.\mathrm{P}=0.001\right)$, biomass dry matter was ranged from 1099.1 (3//1) to $1370.5 \mathrm{~g} \mathrm{~m}^{-2}$ (3//14) under irrigated condition, and $892.6(3 / / 1)$ to $1153.9 \mathrm{~g} \mathrm{~m}^{-2}$ (3//14) under unirrigated condition $(\mathrm{P}=0.05)$, and harvest index were from 25.1 (3//14) to 28.0 (3//1) under irrigated conditions, and 25.9 (3//14) to $31.2(3 / / 1)$ under unirrigated conditions $(\mathrm{P}=0.04)$. Regression analysis, averaging over years, showed a positive relationship between grain yield and biomass under irrigated $\left(R^{2}=0.76 ; P=0.05\right)$, despite that, any positive relation was not found under unirrigated conditions $\left(\mathrm{R}^{2}=0.43 ; \mathrm{P}=0.23\right)$ due to post-anthesis drought stress. A strong relationship was also found between plant height and biomass dry matter under both irrigated $\left(\mathrm{R}^{2}=0.89 ; \mathrm{P}=0.02\right)$ and unirrigated $\left(\mathrm{R}^{2}=0.97 ; \mathrm{P}=0.003\right)$ conditions due to the high contribution of plant height in increasing plant biomass. It is concluded that genotypes had different response to drought due to their genetic diversity, and relatively low impact of water stress was appeared on growth and grain yield of barley in this semi-arid region compared to worldwide expected range of yield reduction.
\end{abstract}

(c) 2021 Production by the University of Garmian. This is an open access article under the LICENSE

https://creativecommons.org/licenses/by-nc/4.0/

Keywords: Barley, Drought tolerance, Yield components, Water-use efficiency.

\section{Introduction}

Barley is one of the most important and sustainable crops in Asia, Africa, America and Europe that farmers can cultivate which covers more than 40 million hectares in water limited environment regions ${ }^{[1]}$. It can grow and yield effectively in a wide range of environmental conditions such as drought-prone and high-temperature, which indicated as least affected by stresses in areas where barley is a major source of food ${ }^{[2]}$. Since barley is a widely distributed crop in arid and semi-arid areas and

* Corresponding author

E-mail address: yadgar.mahmood@garmian.edu.krd (Instructor).

Peer-reviewed under the responsibility of the University of Garmian. it tolerates drought more than most of grain crops, it is necessary to determine which stages are most sensitive to drought and reduce grain yield production ${ }^{[3]}$. It has been studied that the degree of drought stress has an impact on decreasing vegetative growth and increases the sensitivity of barley to water limited during the period of stem elongation, swelling the sheath of ears and grain filling period ${ }^{[4]}$. The worldwide cultivated area of barley is estimated to be around 48.5 million hectare, and producing around 134 million tons with the production capacity of 2.8 tons per hectare ${ }^{[5]}$. In Iraq, barley is a major crop that comes after wheat in terms of cultivated area, production, consuming and industrial uses ${ }^{[6]}$. Therefore, appropriate programs should be adopted for improving its quantitative characteristics, such as grain and its components through 
studying the genetic parameters that control these grain related traits ${ }^{[7]}$.

Drought is the most important limiting factor for crop production and it is becoming an increasingly severe problem in many areas of the world ${ }^{[8]}$. Generally drought stress occurs when the available water in the soil is reduced and atmospheric conditions cause continuous loss of water by transpiration or evaporation [9] Drought incidence and severity has been expected due to climate change and will increase in dry areas ${ }^{[10]}$. World population is also predicted to increase from 7.7 billion to 9.7 billion in 2050 which will extremely increase the global food demand ${ }^{[11]}$. Plants under dry condition change their metabolism to overcome the drought stress, and different growth stages of the crop do not response similarly to water deficit. Seed germination is highly responsive to existing environment. However, the severity of post-anthesis drought stress is a determinant factor for grain yield and needs to be studied ${ }^{[12]}$. Such information is important for plant breeders to select traits for drought tolerance, and for farmers for better crop management to avoid the occurrence of water stress at the critical stages of development. However, due to the long-term domestication of barley and modern breeding and cultivation, the genetic diversity has been significantly narrowed ${ }^{[13]}$. In this experiment, the impact of drought and role of irrigation treatments on grain yield production, biomass, harvest index, and plant height of barley were investigated using five barley hybrids. Comparing the genotypes to have a better yield potential under drought and assessing yield reduction due to water stress were the main objectives of this study. Therefore, these hypothesizes: i) low effect of water stress on barley yield potentials, ii) genotypic variations between genotypes, and iii) associations between growth traits (biomass dry matter and plant height) on grain yield and harvest index, were examined.

\section{Materials and Methods}

\section{1 Plant materials and site conditions}

Tow field experiments were carried out at Kalar Technical Institute, Research Field of Field Crops Department (longitude $45^{\circ} 22^{\prime} 681^{\prime \prime}$ east, latitude $34^{\circ} 21^{\prime} 558^{\prime \prime}$ north, and elevation level of 178 meters) for two seasons of 2016-2017 (Feb 2017 - May 2017; referred to hereafter as 2017) and 2017-2018 (Dec 2017 May 2018; referred to hereafter as 2018). The site environment is semi-arid with limited winter rainfall ${ }^{[14]}$ and Aridisoils type of soil ${ }^{[15]}$. The plant materials were obtained from previous fulldiallel cross investigation by Mahmood, $2010^{[17]}$. In which, five $\mathrm{F}_{2}$ barley hybrids (Hordeum vulgare L.), Local//Zanbaka (3//18), Local//ARTa/3/Avar (3//14), Local//Roho/Zanbaka (3//5), Local//Avar/H/Sout (3//1), Local//Tadmor/Roho (3//4), were tested for grain yield and yield components under drought and irrigated conditions. The total rainfall in the region was $226.1 \mathrm{~mm}$ in 2017 and $287.4 \mathrm{~mm}$ in $2018^{[16]}$, the rainfall distributions data has shown in Table 1. Based on the severity of the drought, complementary irrigation managements were applied for irrigated treatments when necessary (4 times in April and May in 2017 and 6 times in March and mid-late April in 2018) in each season.

Table 1: The distributions of total yearly and monthly rainfalls (mm) in both 2016-2017 and 2017-2018 seasons ${ }^{[18]}$

\begin{tabular}{|c|c|c|c|c|c|c|c|c|}
\hline \multirow{2}{*}{ Seasons } & \multicolumn{7}{|c|}{ Months of the seasons } & \multirow{2}{*}{ Total (mm) } \\
\cline { 2 - 9 } & November & December & January & February & March & April & May & \\
\hline $2016-2017$ & 21.0 & 29.4 & 25.4 & 19.4 & 122.8 & 6.3 & 1.8 & 226.1 \\
\hline $2017-2018$ & 15.7 & 0.0 & 23.2 & 165.4 & 0.0 & 75.1 & 8.0 & 287.4 \\
\hline
\end{tabular}

\section{2. Experimental design and statistical analysis}

Split-plot design was applied for both years using two main plots for the tow irrigation treatments (Fully irrigated and nonirrigated). Genotypes were completely block randomized on the twenty experimental units $\left(1 \mathrm{~m}^{2}\right)$ divided on four blocks (four replicates). Statistical analysis of variance (ANOVA) was carried out using GenStat $19^{\text {th }}$ Edition software (VSN International, 2017) ${ }^{[19]}$ for both years and mean data of the crossing season. Graphs and linear regressions were conducted using GraphPad Prism 8.0.0 software package to find the relationships between traits in both years and for the cross-year mean (GraphPad Prism version 8.0.0, 2019) ${ }^{[20]}$.

\section{3 Crop measurements}

\subsection{Grain Yield $\left(\mathrm{g} \mathrm{m}^{-2}\right)$ and Biomass Dry Matter $\left(\mathrm{g} \mathrm{m}^{-2}\right)$}

In both field trials (2017 and 2018), all plants were harvested in each plot at ground-level around ten days after physiological maturity. The harvested materials were then separated into ears and straw. The ears were threshed and the grains were weighed based on $15 \%$ moisture content after drying for 48 hours at $72{ }^{\circ} \mathrm{C}$ for each plot samples. The remaining materials (straw and chaff) were oven dried for 48 hours at $72 \mathrm{oC}$. Biomass dry matter was then calculated from the sum of grains, straw and chaff for each plot.

\section{3. 2 Plant Height (cm) and Harvest Index}

Plant height was measured on five randomly selected plants from each experimental unit which was using a ruler from the soil surface to the top of the plant ears. The average of plant heights was then calculated to be plant height for each plot. Harvest index was also calculated as the ratio of grain yield and total biomass dry matter of the above-ground biomass.

\section{Results}

\section{1 Grain yield (GY; g m-2)}

In 2017, drought had no significant effect on decreasing grain weight $(\mathrm{P}=0.68)$. Despite that, grain yield was reduced in drought situation by 332.7 to $264.9 \mathrm{~g} \mathrm{~m}^{-2}$ ( $\left.\mathrm{P}=0.001\right)$, and reduced from 319.1 to $282.0 \mathrm{~g} \mathrm{~m}^{-2}(\mathrm{P}=0.002)$ for the cross-year mean in 2018 . Averaging over years, genotype (3//1) had the lowest grain yield reduction $(8.8 \%)$, while genotype (3//18) had the highest rate of (16.3\%). Genotypes were ranged from $283.5(3 / / 5)$ to $328.7 \mathrm{~g} \mathrm{~m}^{-}$ ${ }^{2}$ (3//14) under irrigated conditions, and $287.2(3 / / 1)$ to $315.3 \mathrm{~g} \mathrm{~m}^{-}$ 
2 (3//14) under unirrigated conditions $(\mathrm{P}=0.04)$ in 2017. In 2018, genotypes differed in the ranges $305.6(3 / / 1)$ to $354.7 \mathrm{~g} \mathrm{~m}^{-2}$ (3//18) under irrigated conditions, and $239.5(3 / / 5)$ to $289.3 \mathrm{~g} \mathrm{~m}^{-}$ 2 (3//14) under unirrigated conditions $(\mathrm{P}=0.004)$. For the crossyear mean, genotypes differed in the range 299.1 (3//1) to 336.2 $\mathrm{g} \mathrm{m}^{-2}$ (3//14) under irrigated condition, and $267.8(3 / / 5)$ to 302.3 $\mathrm{g} \mathrm{m} \mathrm{m}^{-2}(3 / / 4)$ under unirrigated condition $(\mathrm{P}=0.001)$. The interaction between irrigation and genotype was not significant in both years and cross-year mean $(\mathrm{P}=0.51, \mathrm{P}=0.26$ and $\mathrm{P}=0.44$, respectively; Table 2).

Table 2: Grain yield (GY; $\mathrm{g} \mathrm{m}^{-2}$ ) under irrigated and unirrigated conditions for 5 genotypes of barley in 2017, 2018 and cross-year mean.

\begin{tabular}{|c|c|c|c|c|c|c|}
\hline \multirow{2}{*}{ Genotypes } & \multicolumn{2}{|c|}{2017} & \multicolumn{2}{|c|}{2018} & \multicolumn{2}{|c|}{$2017-18$} \\
\hline & Irrigated & Unirrigated & Irrigated & Unirrigated & Irrigated & Unirrigated \\
\hline $3 / / 18$ & 316.3 & 290.5 & 354.7 & 270.6 & 335.5 & 280.6 \\
\hline $3 / / 14$ & 328.7 & 315.3 & 343.6 & 289.3 & 336.2 & 302.3 \\
\hline $3 / / 5$ & 283.5 & 296.1 & 334.9 & 239.5 & 309.2 & 267.8 \\
\hline $3 / / 1$ & 292.7 & 287.2 & 305.6 & 258.3 & 299.1 & 272.8 \\
\hline $3 / / 4$ & 306.6 & 305.9 & 324.6 & 266.9 & 315.6 & 286.4 \\
\hline Mean & 305.6 & 299.0 & 332.7 & 264.9 & 319.1 & 282.0 \\
\hline \multicolumn{7}{|l|}{ SED (df) } \\
\hline Year (1) & & & & & & .81) \\
\hline Irrigation (1) & \multicolumn{2}{|c|}{$14.3^{\mathrm{ns}}(0.68)$} & \multicolumn{2}{|c|}{$2.91 * *(0.001)$} & $\frac{14.14^{115}(0.81)}{7.31 * *(0.002)}$ & 002) \\
\hline Genotype (4) & \multicolumn{2}{|c|}{$11.0 *(0.04)$} & \multicolumn{2}{|c|}{$12.31 *(0.04)$} & \multicolumn{2}{|c|}{$8.27 * *(0.001)$} \\
\hline Irri. x Gen. (4) & \multicolumn{2}{|c|}{$20.0^{\mathrm{ns}}(0.51)$} & \multicolumn{2}{|c|}{$15.84^{\mathrm{ns}}(0.26)$} & \multicolumn{2}{|c|}{$12.76^{\mathrm{ns}}(0.44)$} \\
\hline Year x Gen. (4) & \multicolumn{2}{|c|}{-} & \multicolumn{2}{|c|}{-} & \multicolumn{2}{|c|}{$17.58^{\mathrm{ns}}(0.78)$} \\
\hline
\end{tabular}

N.B: $* * *$ denotes $\mathrm{P}<0.001 ; * * \mathrm{P}<0.01$ and $* \mathrm{P}<0.05$ significance levels; $\mathrm{ns}=$ not significant

(SED) Standard error of differences of the means, (df) Degree of freedom

\section{2 Biomass Dry Matter (BDM; g m-2)}

Biomass dry matter was not significantly affected by drought $(\mathrm{P}=0.67)$ in 2017. However, drought reduced BDM from 1221.2 to $800.1 \mathrm{~g} \mathrm{~m}^{-2}$ ( $\left.\mathrm{P}=0.001\right)$, and from 1241.0 to $1003.7 \mathrm{~g} \mathrm{~m}^{-2}$ $(\mathrm{P}=0.67)$ for the cross-year mean in 2018. Genotypes were ranged from $1076.0(3 / / 1)$ to $1517.8 \mathrm{~g} \mathrm{~m}^{-2}(3 / / 14)$ under irrigated conditions, and $1008.5(3 / / 1)$ to $1345.3 \mathrm{~g} \mathrm{~m}^{-2}(3 / / 14)$ under unirrigated conditions $(\mathrm{P}=0.05)$ in 2017. In 2018, genotypes differed in the ranges $1122.1(3 / / 1)$ to $1307.1 \mathrm{~g} \mathrm{~m}^{-2}$ (3//18) under irrigated conditions, and 670.8 (3//4) to $962.5 \mathrm{~g} \mathrm{~m}^{-2}$ (3//14) under unirrigated conditions $(\mathrm{P}=0.001)$. Genotypes differed in the range $1099.1(3 / / 1)$ to $1370.5 \mathrm{~g} \mathrm{~m}^{-2}(3 / / 14)$ under irrigated condition, and $892.6(3 / / 1)$ to $1153.9 \mathrm{~g} \mathrm{~m}^{-2}$ (3//14) under unirrigated condition $(\mathrm{P}=0.05)$ for the cross-year mean. The irrigation $\mathrm{x}$ genotype interactions was not significant in both 2017 and cross-year mean $(\mathrm{P}=0.90$ and $\mathrm{P}=0.90$, respectively), however, it was significant in $2018(\mathrm{P}=0.001$; Table 3$)$.

Table 3: Biomass Dry Matter (BDM; $\mathrm{g} \mathrm{m}^{-2}$ ) under irrigated and unirrigated conditions for 5 genotypes of barley in 2017, 2018 and cross-year mean.

\begin{tabular}{|c|c|c|c|c|c|c|}
\hline \multirow{2}{*}{ Genotypes } & \multicolumn{2}{|c|}{2017} & \multicolumn{2}{|c|}{2018} & \multicolumn{2}{|c|}{$2017-18$} \\
\hline & Irrigated & Unirrigated & Irrigated & Unirrigated & Irrigated & Unirrigated \\
\hline $3 / / 18$ & 1288.0 & 1217.0 & 1307.1 & 866.3 & 1297.6 & 1041.6 \\
\hline $3 / / 14$ & 1517.8 & 1345.3 & 1223.3 & 962.5 & 1370.5 & 1153.9 \\
\hline $3 / / 5$ & 1229.8 & 1287.0 & 1287.8 & 724.2 & 1258.8 & 1005.6 \\
\hline $3 / / 1$ & 1076.0 & 1008.5 & 1122.1 & 776.8 & 1099.1 & 892.6 \\
\hline $3 / / 4$ & 1193.0 & 1179.3 & 1165.5 & 670.8 & 1179.3 & 925.0 \\
\hline Mean & 1260.9 & 1207.4 & 1221.2 & 800.1 & 1241.0 & 1003.7 \\
\hline \multicolumn{7}{|l|}{ SED (df) } \\
\hline Year (1) & & & \multicolumn{2}{|c|}{-} & \multicolumn{2}{|c|}{$92.8^{*}(0.05)$} \\
\hline Irrigation (1) & \multicolumn{2}{|c|}{$115.1^{\text {ns }}(0.67)$} & \multicolumn{2}{|c|}{$36.32 * *(0.001)$} & \multicolumn{2}{|c|}{$115.1^{\mathrm{ns}}(0.67)$} \\
\hline Genotype (4) & \multicolumn{2}{|c|}{$118.5^{*}(0.05)$} & \multicolumn{2}{|c|}{$31.31 * *(0.001)$} & \multicolumn{2}{|c|}{$118.5^{*}(0.05)$} \\
\hline Irri. x Gen. (4) & \multicolumn{2}{|c|}{$189.0^{\text {ns }}(0.90)$} & \multirow{2}{*}{\multicolumn{2}{|c|}{$\begin{array}{c}53.74 * *(0.001) \\
-\end{array}$}} & \multirow{2}{*}{\multicolumn{2}{|c|}{$\begin{array}{l}\frac{189.0^{\mathrm{ns}}(0.90)}{120.9^{\mathrm{ns}}(0.32)}\end{array}$}} \\
\hline Year x Gen. (4) & \multicolumn{2}{|c|}{-} & & & & \\
\hline
\end{tabular}

N.B: $* * *$ denotes $\mathrm{P}<0.001 ; * * \mathrm{P}<0.01$ and $* \mathrm{P}<0.05$ significance levels; $\mathrm{ns}=$ not significant

(SED) Standard error of differences of the means, (df) Degree of freedom

Regression analysis showed a trend for positive relationship between grain yield and biomass in 2017 under both irrigated $\left(\mathrm{R}^{2}=0.61 ; \mathrm{P}=0.12\right)$ and unirrigated conditions $\left(\mathrm{R}^{2}=0.48 ; \mathrm{P}=0.20\right.$;
Figure 1a). In 2018, the relationship was significant under irrigated but not under unirrigated condition $\left(\mathrm{R}^{2}=0.77 ; \mathrm{P}=0.05\right.$ 
and $\mathrm{R}^{2}=0.54 ; \mathrm{P}=0.16$, respectively; Figure $1 \mathrm{~b}$ ). For the cross-year mean, a significant positive correlation was also found under

a) 2017

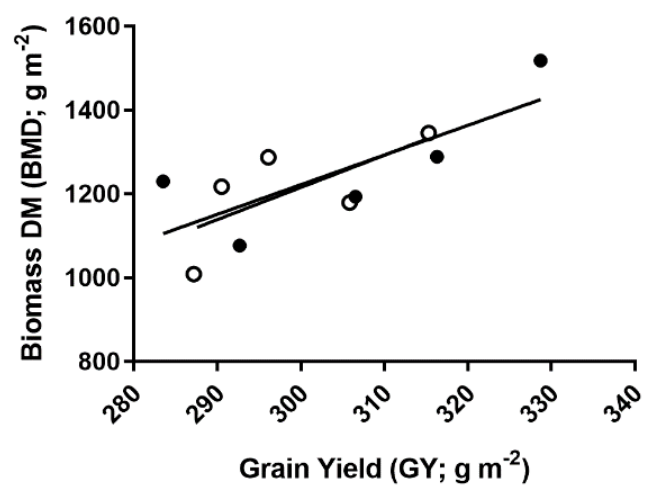

c) $2017-18$

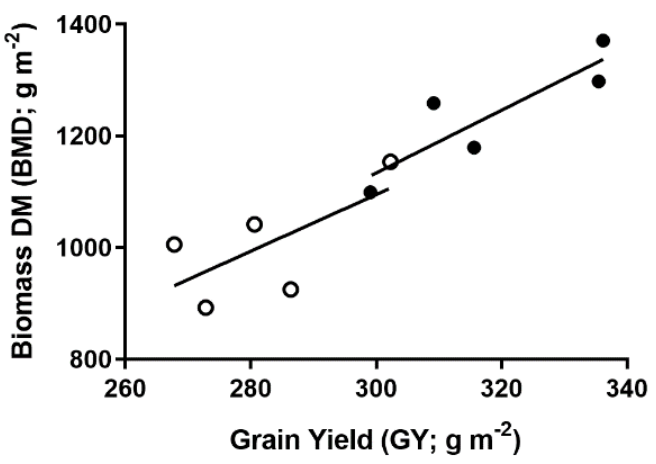

irrigated $\left(\mathrm{R}^{2}=0.76 ; \mathrm{P}=0.05\right)$, but not under unirrigated conditions $\left(\mathrm{R}^{2}=0.43 ; \mathrm{P}=0.23\right.$; Figure $\left.1 \mathrm{c}\right)$.

\section{b) 2018}

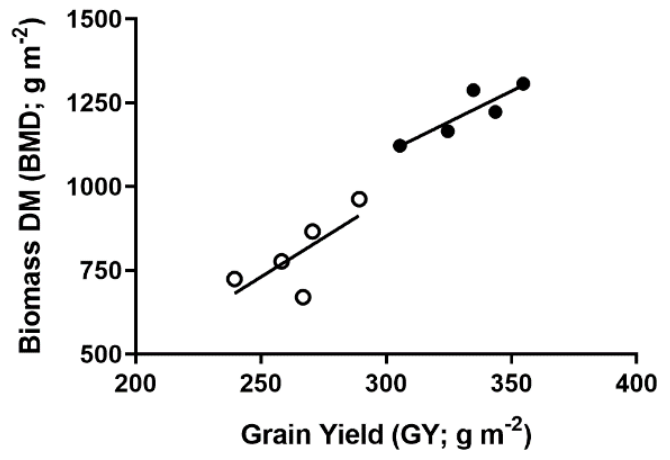

$\rightarrow$ Irrigated

a) $Y=7.080 * X-902.3$

$R^{2}=0.61 ; P=0.12$

b) $Y=3.685^{*} X-4.807$

$R^{2}=0.77 ; P=0.05$

C) $Y=5.618^{*} X-551.8$

$R^{2}=0.76 ; P=0.05$

$$
\begin{aligned}
& \rightarrow \text { Unirrigated } \\
& Y=7.679^{\star} X-1089 \\
& R^{2}=0.48 ; P=0.20 \\
& Y=4.673^{\star} X-437.8 \\
& R^{2}=0.54 ; P=0.16 \\
& Y=5.065^{\star} X-424.3 \\
& R^{2}=0.43 ; P=0.23
\end{aligned}
$$

Figure 1: Linear regressions of grain yield (GY; $\mathrm{g} \mathrm{m}^{-2}$ ) on biomass dry matter (BMD; $\mathrm{g} \mathrm{m}^{-2}$ ) for 5 genotypes of barley in (a) 2017, (b) 2018 and (c) cross-year mean under irrigated and unirrigated conditions

\section{3 Harvest Index (HI)}

Harvest index was not changed significantly $(\mathrm{P}=0.40)$ in 2017 , while, in 2018, it was increased from 27.4 to $32.5(\mathrm{P}=0.01)$ in 2018 , and from 26.6 to $28.8(\mathrm{P}=0.03)$ for the cross-year mean. Genotypes were ranged from 22.1 (3//14) to 28.0 (3//5) under irrigated conditions, and 21.7 (3//14) to 27.5 (3//18) under unirrigated conditions $(\mathrm{P}=0.05)$ in 2017. In 2018, genotypes did not significantly differ $(\mathrm{P}=0.45)$, while for the cross-year mean,

\begin{tabular}{|c|c|c|c|c|c|c|}
\hline \multirow{2}{*}{ Genotypes } & \multicolumn{2}{|c|}{2017} & \multicolumn{2}{|c|}{2018} & \multicolumn{2}{|c|}{$2017-18$} \\
\hline & Irrigated & Unirrigated & Irrigated & Unirrigated & Irrigated & Unirrigated \\
\hline $3 / / 18$ & 24.7 & 27.5 & 27.2 & 31.3 & 25.9 & 29.4 \\
\hline $3 / / 14$ & 22.1 & 21.7 & 28.2 & 30.1 & 25.1 & 25.9 \\
\hline $3 / / 5$ & 28.0 & 22.2 & 26.5 & 33.1 & 27.2 & 27.7 \\
\hline $3 / / 1$ & 27.0 & 25.6 & 27.2 & 33.3 & 28.0 & 31.2 \\
\hline $3 / / 4$ & 25.9 & 25.3 & 27.9 & 34.8 & 26.9 & 30.0 \\
\hline Mean & 25.5 & 24.5 & 27.4 & 32.5 & 26.6 & 28.8 \\
\hline \multicolumn{7}{|l|}{ SED (df) } \\
\hline Year (1) & \multicolumn{2}{|c|}{-} & \multicolumn{2}{|c|}{-} & \multicolumn{2}{|c|}{$0.894 * *(0.001)$} \\
\hline Irrigation (1) & \multicolumn{2}{|c|}{$1.082^{\mathrm{ns}}(0.40)$} & \multicolumn{2}{|c|}{$0.973 * *(0.01)$} & \multicolumn{2}{|c|}{$0.728 *(0.03)$} \\
\hline Genotype (4) & \multicolumn{2}{|c|}{$1.503 *(0.05)$} & \multicolumn{2}{|c|}{$1.286^{\mathrm{ns}}(0.45)$} & \multicolumn{2}{|c|}{$0.989 *(0.04)$} \\
\hline Irri. x Gen. (4) & \multicolumn{2}{|c|}{$2.187^{\mathrm{ns}}(0.12)$} & \multicolumn{2}{|c|}{$1.896^{\mathrm{ns}}(0.30)$} & \multicolumn{2}{|c|}{$1.447^{\mathrm{ns}}(0.44)$} \\
\hline Year x Gen. (4) & \multicolumn{2}{|c|}{-} & \multicolumn{2}{|c|}{-} & \multicolumn{2}{|c|}{$1.537^{\mathrm{ns}}(0.27)$} \\
\hline
\end{tabular}
genotypes differed in the range 25.1 (3//14) to 28.0 (3//1) under irrigated conditions, and $25.9(3 / / 14)$ to $31.2(3 / / 1)$ under unirrigated conditions $(\mathrm{P}=0.04)$. Both years and cross-year mean $(\mathrm{P}=0.12, \mathrm{P}=0.30$ and $\mathrm{P}=0.44$, respectively) was not affected by interaction between irrigation and genotype (Table 4).

Table 4: Harvest index (HI) under irrigated and unirrigated conditions for 5 genotypes of barley in 2017, 2018 and cross-year mean.

N.B: ***denotes $\mathrm{P}<0.001 ; * * \mathrm{P}<0.01$ and $* \mathrm{P}<0.05$ significance levels; $\mathrm{ns}=$ not significant

(SED) Standard error of differences of the means, (df) Degree of freedom 


\section{4 Plant height $(\mathrm{PH} ; \mathrm{cm})$}

Plant height was not affected by drought in $2017(\mathrm{P}=0.42)$. However, in 2018, drought decreased Plant height (PH) from 67.0 to $60.3 \mathrm{~cm}(\mathrm{P}=0.01)$, and from 83.3 to $77.9 \mathrm{~cm}(\mathrm{P}=0.05)$ for the cross-year mean. Genotypes were not significantly different in both years and cross year mean $(\mathrm{P}=0.83, \mathrm{P}=0.44$ and $\mathrm{P}=0.41$, respectively). The interactions between irrigation and genotype was also not significant in both years and cross-year mean $(\mathrm{P}=0.99, \mathrm{P}=0.82$ and $\mathrm{P}=0.95$, respectively; Table 5).

Table 5: Plant height (P.H) under irrigated and unirrigated conditions for 5 genotypes of barley in 2017, 2018 and cross-year mean.

\begin{tabular}{|c|c|c|c|c|c|c|}
\hline \multirow{2}{*}{ Genotypes } & \multicolumn{2}{|c|}{2017} & \multicolumn{2}{|c|}{2018} & \multicolumn{2}{|c|}{$2017-18$} \\
\hline & Irrigated & Unirrigated & Irrigated & Unirrigated & Irrigated & Unirrigated \\
\hline $3 / / 18$ & 99.6 & 96.2 & 67.2 & 61.2 & 83.4 & 78.7 \\
\hline $3 / / 14$ & 102.6 & 98.6 & 66.9 & 64.6 & 84.8 & 81.6 \\
\hline $3 / / 5$ & 99.1 & 95.8 & 69.0 & 61.2 & 84.0 & 78.5 \\
\hline $3 / / 1$ & 99.4 & 92.6 & 64.3 & 56.4 & 81.9 & 74.5 \\
\hline $3 / / 4$ & 97.3 & 94.6 & 67.4 & 58.2 & 82.4 & 76.4 \\
\hline Mean & 99.6 & 95.6 & 67.0 & 60.3 & 83.3 & 77.9 \\
\hline \multicolumn{7}{|l|}{ SED (df) } \\
\hline Year (1) & \multicolumn{2}{|c|}{ 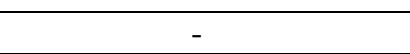 } & \multicolumn{2}{|c|}{ 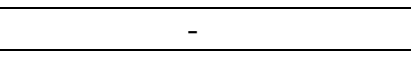 } & \multicolumn{2}{|c|}{$1.483 * *(0.001)$} \\
\hline Irrigation (1) & \multicolumn{2}{|c|}{$4.37^{\mathrm{ns}}(0.42)$} & \multicolumn{2}{|c|}{$1.242 * *(0.01)$} & \multicolumn{2}{|c|}{$2.27 *(0.05)$} \\
\hline Genotype (4) & \multicolumn{2}{|c|}{$4.41^{\mathrm{ns}}(0.83)$} & \multicolumn{2}{|c|}{$3.051^{\mathrm{ns}}(0.44)$} & \multicolumn{2}{|c|}{$2.683^{\text {ns }}(0.41)$} \\
\hline Irri. x Gen. (4) & \multicolumn{2}{|c|}{$7.09^{\mathrm{ns}}(0.99)$} & \multicolumn{2}{|c|}{$4.054^{\text {ns }}(0.82)$} & \multicolumn{2}{|c|}{$4.083^{\text {ns }}(0.95)$} \\
\hline Year x Gen. (4) & \multicolumn{2}{|c|}{-} & \multicolumn{2}{|c|}{-} & \multicolumn{2}{|c|}{$3.703^{\text {ns }}(0.27)$} \\
\hline
\end{tabular}

N.B: ***denotes $\mathrm{P}<0.001 ; * * \mathrm{P}<0.01$ and $* \mathrm{P}<0.05$ significance levels; $\mathrm{ns}=$ not significant

(SED) Standard error of differences of the means, (df) Degree of freedom

Biomass dry matter showed a strong positive linear relationship with plant height amongst genotypes in 2017 under unirrigated conditions $\left(\mathrm{R}^{2}=0.88 ; \mathrm{P}=0.02\right)$, but not under irrigated conditions $\left(\mathrm{R}^{2}=0.63 ; \mathrm{P}=0.11\right.$; Figure $\left.2 \mathrm{a}\right)$. In 2018 , there was no significant relationship between biomass dry matter and plant height under

a) 2017

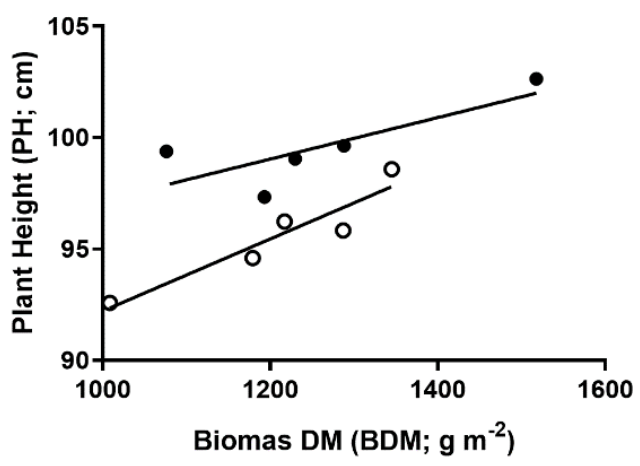

c) 2017-18

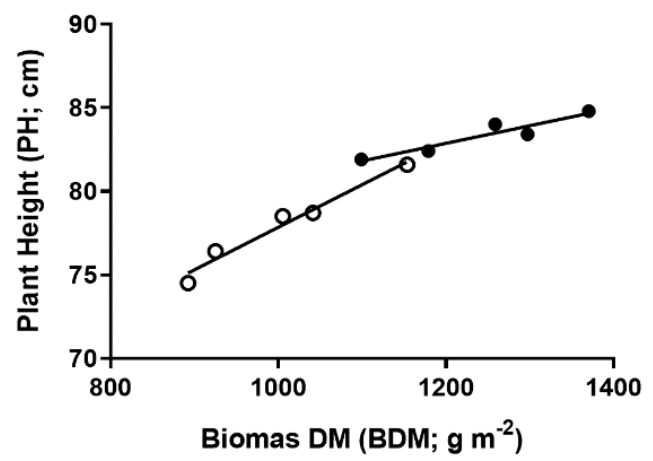

irrigated $\left(\mathrm{R}^{2}=0.54 ; \mathrm{P}=0.16\right)$ and unirrigated $\left(\mathrm{R}^{2}=0.51 ; \mathrm{P}=0.17\right.$; Figure 2b) conditions. Averaging across years, however, a strong positive relationship was found under both irrigated $\left(\mathrm{R}^{2}=0.89\right.$; $\mathrm{P}=0.02)$ and unirrigated $\left(\mathrm{R}^{2}=0.97 ; \mathrm{P}=0.003\right.$; Figure 2c) conditions.

\section{b) 2018}

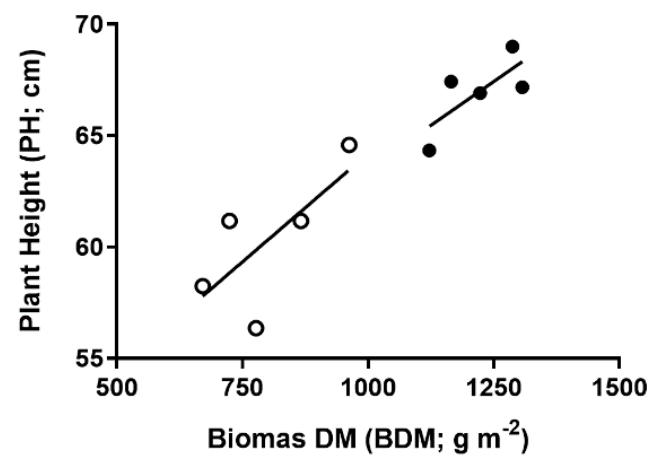

Irrigated

a) $Y=0.009^{*} X+87.87$

$R^{2}=0.63 ; P=0.11$

b) $Y=0.015^{\star} X+47.79$

$R^{2}=0.54 ; P=0.16$

c) $Y=0.010 * X+70.21$

$R^{2}=0.89 ; P=0.02$

Figure 2: Linear regressions of biomass dry matter (BMD; $\mathrm{g} \mathrm{m}^{-2}$ ) on plant height $(\mathrm{PH}$; $\mathrm{cm}$ ) for 5 genotypes of barley in (a) 2017, (b) 2018 and (c) cross-year mean under irrigated and unirrigated conditions. 


\section{Discussions}

Drought stress might fluctuate across years, and consequently might affect barley at different growth stages, therefore, the high drought stress severity, the more grain yield decreased ${ }^{[21]}$. In this study, drought stress had no significant effects on grain yield, biomass dry matter and plant height in 2017 due to the time drought stress occurred when plants arrived late grain-filling stage. However, in 2018, drought occurred between anthesis and early grain-filling stages. Therefore, drought significantly reduced grain yield, harvest index and plant height in 2018 and for the cross year mean. This reduction in grain yield may mostly due to the effect of water stress on grain related traits at early grain-filling duration such as grain weight and number of grains [22 and 23]. It has been confirmed by previous studies that water stress leads to growth reduction which is reflected on plant height, leaf area, dry weight, and other growth functions [24, 25 and 26]. However, grain yield reduction was ranged from $8.8-16.3 \%$ in this study, while $49-87 \%$ is expected under severe drought stress [3 and 27]. Under optimal conditions (fully irrigated), a significant relationship was found between grain yield and biomass dry matter, while under water stress the relationship was weak. This may relate to the effect of post-anthesis drought stress when plant biomass growth has reached the maximum level ${ }^{[28]}$. Indeed, during the stressed condition the relationship between sink and the source of biological product will be shifted and not constitute normal schedule ${ }^{[29]}$. Averaging over years, a strong correlation was found between plant height and biomass dry matter due to the high contribution of plant height in increasing plant biomass [30 and 31]. Therefore, biomass dry matter and plant height can be used as selection criterion for grain yield performance under drought conditions. Worldwide, some agronomic and morphological traits have been tested for drought tolerance, including grain yield ${ }^{[32]}$, biomass dry matter ${ }^{[33 \text { and } 34]}$.

\section{Conclusions}

The results of this study indicated that drought stress has significantly affected grain yield and all of the yield components. However, the rate of grain yield loss was between (8.8-16.3\%) averaging over years, while the reduction is expected to be (49$87 \%$ ) under severe drought stress ${ }^{[3}$ and 27$]$. Generally, Garmian region climate can be more appropriate for barley production compared to other field crops in Kurdistan and Iraq, and improving new variety from local genetic materials through a breeding program is necessary. Genotype (3//1) is therefore highly suggested to be more screened and improved for a better yield performance under this arid and semi-arid climate condition.

\section{References}

1. Grando, S., von Bothmer, R. and Ceccarelli, S. Genetic diversity of barley: use of locally adapted germplasm to enhance yield and yield stability of barley in dry areas, CABI/FAO/IPRI, pp. 351-372 (2016)

2. Lehmann, L.C., and von Bothmer, R. Hordeum spontaneum and landraces as a gene resource for barley breeding. In: "Cereal breeding related to integrated cereal production" Jorna, M.L. and Slootmaker L.A.J. (eds.). Pudoc, Wageningen, the Netherlands, pp. 190-194 (1988)

3. Cai, K., Chen, X., Han, Z., Wu, X., Zhang, S., Li, Q., Nazir, M.M., Zhang, G. and Zeng, F. Screening of Worldwide Barley Collection for Drought Tolerance: The
Assessment of Various Physiological Measures as the Selection Criteria. Front. Plant Sci. 11:1159. https://doi.org/10.3389/fpls.2020.01159, (2020)

4. Ashoub, A., Beckhaus, T., Berberich, T., Karas, M. and Brüggemann, W. Comparative analysis of barley leaf proteome as affected by drought stress. Planta, 237, 771-781, https://doi.org/10.1007/s00425-012-1798-4, (2013)

5. Bothmer, R., Sato, K., Komatsuda, T., Yasuda, S. and Fischbeck, G. Chapter 2 The domestication of cultivated barley. Developments in Plant Genetics and Breeding, 7 , 9-27. https://doi.org/10.1016/S0168-7972(03)80004-X, (2003)

6. Hassan, H., Mohammed, M., Mahmood, Y. Association between some grain related traits of barley under drought and irrigated conditions. Journal of Garmian University, 6 (SCPAS Conferance), pp. 76-83. https://doi.org/10.24271/garmian.scpas10, (2019)

7. Roghzai, Y.A.M., The physiological and genetic bases of drought tolerance in bread wheat and ancestral wheat species. $\mathrm{PhD}$ thesis submitted to the University of Nottingham, school biosciences, crop and plant sciences department, (2016)

8. Passioura, J.B. Drought and drought tolerance. Plant Growth Regulation, 20(2), 79-83, (1996)

9. Khajeh, H.M., Powell, A.A., Bingham, L.J. The interaction between salinity stress and seed Vigor during germination of soybean seed. Seed Sci. Technol, 1, 715-725, (2003)

10. Intergovernmental Panel on Climate Change, Climate Change 2013 - The Physical Science Basis. Cambridge University Press. https://doi.org/10.1017/CBO9781107415324, (2014)

11. United Nations: Department of Economic and Social Affairs - Population Division, World Population Prospects 2019: Highlights. United Nations Publ., New York City, 2-3. (2019)

12. Aspinall D., The effects of soil moisture stress on the growth of barley: II. Grain Growth, Aust. J. Agr. Res., 16 265-275, (1965)

13. Nevo, E., and Chen, G. Drought and salt tolerances in wild relatives for wheat and barley improvement. Plant Cell Environ. 33, 670-685. https://doi.org/10.1111/j.13653040.2009.02107.x, (2010)

14. Walter, H. and Leith, H. Climadigram welt atlas. Jena, 4: 434, (1960)

15. Aziz, S.N. Survey and classification of some soils from Kurdistan region. M.Sc. thesis submitted to the University of Sulaimani, college of agriculture, (2006)

16. Mahmood, Y.A., Mohammed, M.S. and Hassan, H.N. A physiological Explanation of Drought Effect on Flag-Leaf Specific Weight and Chlorophyll Content of Barley, Iraqi Journal of Science, 60(12), pp. 2531-2539, https://doi.org/10.24996/ijs.2019.60.12,1, (2019)

17. Mahmood, Y.A., Full Diallel Crosses in Two-rowed Barley (Hordeum vulgare L.). M.Sc. thesis submitted to the University of Sulaimani, college of agriculture, (2010)

18. Mahmood, Y.A. Drought effects on leaf canopy temperature and leaf senescence in barley, Iraqi Journal of Agricultural Sciences, 51(6):1684-1693, (2020)

19. VSN International, Genstat for Windows. 19th Edition. VSN International, Hemel Hempstead, UK, (2017)

20. GraphPad Prism version 8.0.0 for Windows. Linear regression analysis was performed using graphPad Software, San Diego, California USA, www.graphpad.com, (2019)

21. Fischer, R.A., Turner, N.C. and Kramer, P. (Eds.), Adaptation of plants to water and high temperature stress, Willey and Son, New York, pp. 323-340, (1980)

22. Monneveux, P., Reynolds, M.P., Trethowan, R., González-Santoyo, H., Peña, R.J., and Zapata, F. Relationship between grain yield and carbon isotope discrimination in bread wheat under four water regimes. European Journal of Agronomy, 22(2), 231242, (2005)

23. Kadam, N.N., Xiao, G., Melgar, R.J., Bahuguna, R.N., Quinones, C. and Tamilselvan, A. Chapter Three - Agronomic and physiological responses to high temperature, drought, and elevated $\mathrm{CO} 2$ interactions in cereals, Advances in Agronomy. Ed. Sparks, D. (Salt Lake City: Academic Press), 111-156. https://doi.org/10.1016/B9780-12-800131-8.00003-0, (2014)

24. Bendig, J., Yu, K., Aasen, H., Bolten, A., Bennertz, S., Broscheit, J. and Bareth, G. Combining UAV-based plant height from crop surface models, visible, and near infrared vegetation indices for biomass monitoring in barley. International Journal of Applied Earth Observation and Geoinformation, 39, 79-87, (2015) 
25. Slack, S., York, L.M., Roghazai, Y., Lynch, J., Bennett, M. and Foulkes, J. Wheat shovelomics II: Revealing relationships between root crown traits and crop growth. BioRxiv 280917, https://doi.org/10.1101/280917, (2018)

26. Fischer, R.A. and Maurer, R. Drought Resistance in Spring Wheat Cultivars. I Grain Yield Responses. Australian Journal of Agricultural Research 29, 897-912, (1978)

27. Samarah, N.H., Alqudah, A.M., Amayreh, J.A., McAndrews, G.M. The effect of lateterminal drought stress on yield components of four barley cultivars. J. Agron. Crop Sci. 195, 427-441. https://doi.org/10.1111/j.1439-037X.2009.00387.x, (2009)

28. Barati, M., Majidi, M. M., Mirlohi, A., Pirnajmodini, F., and Sharifmoghaddam, N. Response of cultivated and wild barley germplasm to drought stress at different developmental stages. Crop Sci. $55 \quad$ (6), 2668-2681. https://doi.org/10.2135/cropsci2015.04.0229, (2015)

29. Serrago, R., Alzueta, I., Savin, R. and Slafer, G. Understanding grain yield responses to source-sink ratios during grain filling in wheat and barley under contrasting environments. Field Crops Research, 150:42-51. https://doi.org/10.1016/j.fcr.2013.05.016, (2013)

30. Innes, P., Hoogendoorn J., Blackwell, R.D. Effects of difference in date of early emergence and height on yield of winter Wheat. J. Agric. Sci. Camb. 105:543-549, (1985)

31. Jouyban, A., Give, H.S., Noryan, M. Relationship between agronomic and morphological traits in barley varieties under drought stress condition. International Research Journal of Applied and Basic Sciences, 9 (9): 1507-1511, (2015)

32. Mwadzingeni, L., Shimelis, H., Tesfay, S., and Tsilo, T. J. Screening of bread wheat genotypes for drought tolerance using phenotypic and proline analyses. Front. Plant Sci. 7, 1276. https://doi.org/10.3389/fpls.2016.01276, (2016)

33. Zhao, J., Sun, H., Dai, H., Zhang, G., and Wu, F. Difference in response to drought stress among Tibet wild barley genotypes. Euphytica 172, 395-403. https://doi.org/10.1007/s10681-009-0064-8, (2010)

34. Szira, F., Bá lint, A.F., Börner, A., and Galiba, G. Evaluation of drought related traits and screening methods at different developmental stages in spring barley. J. Agron. Crop Sci. 194, 334-342. https://doi.org/10.1111/j.1439-037X.2008.00330.x, (2008). 